\title{
TEORI MUTAKHIR PEMBELAJARAN: KONSEP EDUTAINMENT DALAM PEMBELAJARAN PENDIDIKAN AGAMA ISLAM
}

\author{
Ulil Albab \\ Mahasiswa Pascasarjana Manajemen Pendidikan Islam \\ UIN Sunan Kalijaga Yogyakarta
}

Email: e.ulilalbab@yahoo.co.id

\begin{abstract}
Education, in its essence, is the process to direct human into significant development in discovering, nurturing and producing the highest degree of human potential. These diverse human faculties are far wider than education old paradigm intends to achieve: knowledge transformation. Thus, entertaining education tries to actualize conventional learning objectives while maintaining neglected objectives. One of the concept in entertaining education, edutainment, tries to combine two disctinct activities: education and entertainment. In the context of Islamic Education which aims a multidimensional purpose of belief, action, character and being beneficial for both religion and nation, implementing edutainment is a proper act, for it will provide freedom for student to explore knowledges from different sources, as well as nurturing other hidden human potentials. This article discusses the concept of edutainment and several mechanism to implement it comprehensively in Islamic Education.
\end{abstract}

Keywords: Learning, Edutainment, Islamic Education

\section{PENDAHULUAN}

Istilah yang sering kita dengar mengenai pendidikan adalah proses transfer of knowledge. Pendidikan, menurut pengertian ini, menginisiasikan adanya interaksi antara seorang yang sudah tahu dengan yang belum tahu. Dengan kata lain, pendidikan adalah memberikan pangetahuan kepada yang menginginkan pengetahuan. Sederhananya, menurut teori ini, guru memberikan pelajaran, sendangkan murid mendengarkan yang di sampaikan oleh guru.

Perkembangan zaman yang begitu pesat menuntut terwujudnya ide-ide inovatif dalam segala 


\section{Ulil Albab}

hal, termasuk dunia pendidikan. Dari masa ke masa, dunia pendidikan mengalami perubahan. Hal ini terbukti dengan adanya penemuan-penemuan baru, yang sekaligus menunjukkan bahwa pendidikan selalu bersifat maju (taqaddumiyyah) dan berorientasi ke depan (future oriented). Dalam perkembangannya, tren dunia pendidikan abad 21 lebih berorientasi pada pengembangan potensi manusia, dan tidak lagi memusatkan pada kemampuan teknikal dalam melakukan eksplorasi dan eksploitasi alam sebagaimana pada abad ke 20 (Hamruni, 2009:1). Pergeseran ini didorong tidak hanya oleh kenyataan terjadinya krisis ekologi, tetapi juga oleh hasil riset terutama dalam bidang neuropsikologi.

Neuropsikologi adalah suatu bidang interdisiplin antara neurologi dan psikologi. Neuropsikologi mempelajari hubungan antara otak dan perilaku, disfungsi otak dan defisit perilaku, dan melakukan assesment dan treatment untuk perilaku yang berkaitan dengan fungsi otak yang terganggu (Nurussakinah Daulay, 2017:15). Assesment neuropsikologis adalah sebuah metode untuk menggambarkan fungsi otak berdasarkan pada performa pasien melalui tes-tes yang di standarisasi, yang telah terbukti memiliki indikator akurat mengenai hubungan otak dan perilaku. Otak menerima berbagai macam informasi melalui panca indera sebelum diinterpretasikan dalam perilaku konkrit. Informasi yang diterima oleh otak manusia, akan tersimpan dalam memorinya, baik memori jangka pendek maupun jangka panjang. Informasi tersebut amat mempengaruhi perilaku manusia. Pertanyaannya adalah, darimana manusia memperoleh informasi? Informasi dapat diperoleh dari berbagai sumber, salah satunya dengan cara belajar dan melalui serangkaian proses pembelajaran.

Menurut Sanaky, proses pembelajaran pada khakikatnya adalah proses komunikasi, yaitu proses penyampaian pesan dari sumber pesan ke penerima pesan melalui saluran atau media tertentu (2013:11). Lebih lanjut, Arif S.Sadiman dalam Sanaky (2013:12) menyatakan bahwa komponen komunikasi dalam proses pembelajaran adalah: (a) pengajar dapat menjalankan fungsinya sebagai pemberi pesan (komuniator), (b) pembelajar sebagai penerima pesan (komunikan), (c) materi pelajaran sebagai pesan, (d) alat pembantu pembelajaran sebagai saluran atau media pembelajaran, (e) faktor lain dalam pembelajaran adalah umpan balik yang merupakan manifestasi berupa pertanyaan, jawaban, dan persilangan pendapat. Komunikasi akan mudah tersampaikan apabila komunikan siap menerima dan tidak merasa di paksa maka terjadilah suasana menyenangkan dalam pembelajaran.

Perkembangan dalam dunia pendidikan tersebut membuat pendidikan pada hari ini tidak lagi dapat direduksi menjadi proses transfer of knowledge. Pendidikan yang menyenangkan memperhatikan juga prinsip-prinsip manusiawi. Pembelajaran menyenangkan mempengaruhi suasana belajar mengajar yang dapat memusatkan perhatiannya secara penuh saat belajar sehingga curah waktu perhatiannya (time on task) tinggi. Pembelajaran menyenangkan 
dapat diartikan sebagai pembelajaran yang dapat menarik perhatian siswa dengan berbagai metode yang diterapkan, sehingga saat pembelajaran berlangsung siswa tidak merasa bosan (Trinova, 2012:212). Dengan demikian, dapat dikatakan bahwa pembelajaran menyenangkan adalah suatu proses pembelajaran yang berlangsung dalam suasana yang menyenangkan dan mengesankan. Suasana pembelajaran yang menyenangkan dan berkesan akan menarik minat peserta didik untuk terlibat secara aktif, sehingga tujuan pembelajaran dapat tercapai maksimal.

Efektif adalah kata kunci keberhasilan sebuah pembelajaran. Namun kiat-kiat untuk menciptakan efektifitas dalam pembelajaran tidaklah semudah membalikkan telapak tangan. Guru sebagai penentu efektif dan tidaknya pembelajaran, sangat dituntut untuk menciptakan metode dan strategi mengajar secara kreatifitas. Hal ini akan sulit dicapai apabila dalam pelaksanaannya masih menggunakan pendekatan yang cenderung kaku dan membosankan, justru menimbulkan kesan negatif pada belajar. Belajar menyenangkan akan mempengaruhi kinerja otak dalam memproses, menyimpan dan mengambil informasi yang ada, sehingga tercipta proses belajar yang efektif.

Efektifitas dalam pembelajaran tentu tidak mungkin tercapai tanpa adanya faktor lain yang menunjang seperti media berajar yang memadai serta lingkungan yang mendukung. Oleh karena itu, suatu lembaga pendidikan (termasuk lembaga pendidikan Islam) membutuhkan strategi yang tepat dalam mentransformasikan materi kepada peserta didik. Untuk itu, lembaga pendidikan perlu mengubah paradigma mengajar yang masih bersifat teachercentered menjadi student-centered. Pembelajaran yang menyenangkan sesungguhnya tercantum dalam Undang-Undang No. 20, pasal 40 ayat 2 yang berbunyi: "guru dan tenaga kependidikan berkewajiban menciptakan suasana pendidikan yang bermakna, menyenangkan, kreatif, dinamis, dan dialogis." Lebih lanjut, Peraturan Pemerintah No.19 tahun 2005 pasal 19 ayat 1 menyatakan: "proses pembelajaran pada satuan pendidikan diselenggarakan secara interaktif, inspiratif, menyenangkan, menantang, memotivasi siswa untuk berpartisipasi aktif, memberikan ruang gerak yang cukup bagi prakarsa, kreativitas, dan kemandirian sesuai dengan bakat, minat dan perkembangan fisik, serta psikologi siswa."

Untuk kegunaan praktis, ada banyak literatur yang membahas teknik pembelajaran menyenangkan yang dapat digunakan oleh para guru. Di antaranya adalah konsep yang diistilahkan dengan kata PAKEM atau PAIKEM. Demikian pula beberapa pendekatan lain seperti quantum teaching, contextual teaching, dan active learning. Namun, meski sudah terdapat banyak metode pembelajaran menyenangkan, masih sedikit para guru yang tertarik untuk menggunakannya. Hal ini mungkin disebabkan keterbatasan waktu untuk membaca literatur tentang materi terkait. 


\section{Ulil Albab}

Konsep lain yang tergolong baru dalam dunia pembelajaran adalah konsep edutainment yang menggabungkan dua unsur education dan intertaiment. Kegiatan belajar yang menyenangkan akan lebih mudah terlaksana apabila aplikasi pembelajaran bersandingan dengan hiburan.

Dalam konteks pendidikan Islam, lembaga pendidikan Islam seperti madrasah, pondok pesantren, dan lembaga pendidikan Islam lainnya, perlu menilik pendekatan-pendekatan pembelajaran baru seperti yang dijelaskan di atas, agar tidak tertinggal dengan lembaga pendidikan umum yang sudah mengaplikasikannya dan membuktikan keberhasilannya.

\section{PEMBAHASAN}

\section{Konsep Edutainment}

Edutaniment merupakan akronim dari dua kata bahasa Inggris, yaitu education dan entertaimet. Education artinya pendidikan, sedangkan entertaiment berarti hiburan. Jika dilihat dari dua kata tersebut, dapat dilihat bahwa edutainment berarti melakukan pembelajaran secara menyenangkan. Hamruni kemudian menyimpulkan bahwa edutainment adalah suatu proses pembelajaran yang didesain dengan memadukan antara muatan pendidikan dan hiburan secara harmonis sehingga aktivitas pembelajaran berlangsung menyenangkan (Hamruni, 2009: 50).

Menurut New World Encyclopedia, edutainment berasal dari kata educational entertaiment atau entertaiment education, yang berarti suatu hiburan yang di desain untuk mendidik dan menghibur. Pada dasarnya, edutainment berusaha mengajarkan atau memfasilitasi interaksi social kepada peserta didik dengan memasukkan berbagai pelajaran dalam bentuk hiburan yang sudah akrab di telinga mereka (Moh. Sholeh Hamid, 2011: 18).

Konsep belajar berwawasan edutainment mulai diperkenalkan secara formal pada taun 1980an, dan telah menjadi satu metode pembelajaran yang sukses dan membawa pengaruh luar biasa pada bidang pendidikan dan peatihan di era millennium ini. Belajar yang menyenangkan menurut konsep edutainment ini bisa dilakukan dengan menyelipkan humor dan permainan (game) ke dalam proses pembelajaran, tetapi juga bisa dengan cara-cara lain, misalnya dengan menggunakan metode bermain peran (role play), demonstrasi, dan multimedia (Maftuh, 2017: 125).

Terkait dengan pembelajaran edutainment, Hamruni menjelaskan ada tiga asumsi yang menjadi landasan dalam pelaksanaan pembelajaran (Hamruni, 2008: 8-9). Pertama, perasaan positif (senang/gembira) akan mempercepat pembelajaran. Sedangkan negatif seperti sedih, takut, terancam dan perasaan tidak mampu akan memperlambat belajar bahkan bisa 
menghentikannya sama sekali. Maka kosep edutainment mencoba memadukan dua aktivitas yang tadinya terpisah dan tidak berhubungan (yakni pendidikan dan hiburan). Kedua, jika seseorang mampu menggunakan potensi nalar emosinya secara jitu, maka ia akan membuat loncatan prestasi belajar yang tidak terduga sebelumnya. Dengan menggunakan metode tepat, peserta didik bisa meaih prestasi belajar berlipat ganda. Ketiga, apabila setiap peserta didik dapat dimotivasi dengan tepat dan diajar dengan cara yang benar, menghargai gaya belajar mereka, maka tercapai hasil belajar yang optimal.

Edutainment adalah pembelajaran yang berlangsung dan dilakukan dengan pendekatan yang bersifat pembelajar sebagai pusat dari proses pembelajaran sekaligus sebagai subyek pendidikan (Hamruni, 2008:10). Konsep pembelajaran edutainment mengarahkan pendekatan student center, yang tidak lagi menjadi sasaran pembelajaran tetapi sebagai pelaku pembelajaran. Dihiasi dengan menampilan peserta didik aktif, senang, dan bergairah setiap jam pelajaran tanpa ada istilah membosankan atau pernyataan tidak sanggup lagi, dan evaluasi setiap materi hasilnya sangat memuaskan (Nasution, 2017: 70).

Konsep Edutainment membuat peserta didik merasa tidak sedang belajar, tetapi sedang melakukan kegiatan yang menyenangkan dan tetap mendapatkan suatu pembelajaran. Seperti firman Allah dalam al-Qur'an surat al-Baqarah ayat 185 yang berbunyi:

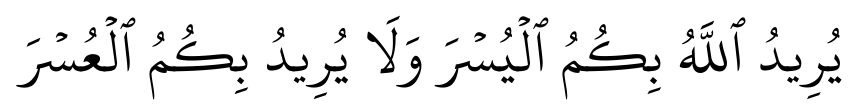

Artinya: "Allah menghendaki kemudahan bagimu, dan tidak menghendaki kesukaran bagimu.” (QS. Al-Baqarah: 185).

Dalam pembelajaran, perintah dan anjuran untuk memberikan kemudahan dan suasana gembira telah banyak diungkapkan dalam berbagai hal. Pada dasarnya ketika seseorang senang melakukan sesuatu, maka mereka cenderung mengingat dan mudah mengikuti terhadap apa yang disenangi, termasuk dalam belajar. Peserta didik yang merasa senang terhadap suatu mata pelajaran tertentu, mereka akan mudah menangkap materi yang diajarkan, selalu memperhatikan dan menghasilkan produk belajar yang berkualitas kedepannya.

Jadi pembelajaran Edutainment merupakan inovasi atas perkembangan teori pembelajaran yang telah dilakukan sebelumnya. Edutainment menjadikan peserta didik sebagai subjek bukan lagi sebagai objek penerima. Mereka diberi kebebasan untuk mengeksplorasi kemampuan yang dimiliki, dengan pembelajaran penuh hiburan sehngga menciptakan keaktifan dan kreativitas potensi diri. 


\section{Ulil Albab}

\section{Prinsip Pembelajaran Edutainment}

Pada hakikatya prinsip pembelajaran edutainment memberikan penegasan terhadap konsep pembelajaran yang menyenangkan. Berikut prinsip-prinsip pembelajaran edutainment yang dipaparkan oleh Suyadi (2010: 228):

1. Rangkaian pendekatan dalam pembelajaran untuk menjembatani jurang yang memisahkan antara proses mengajar dan proses belajar sehingga diharapkan bisa meningkatkan hasil belajar. Konsep ini dirancang agar proses belajar mengajar dilakukan secara holistik dengan menggunakan pengetahuan yang berasal dari berbagai disiplin ilmu seperti pengetahuan tentang cara kerja otak dan memori, motivasi, konsep diri, emosi (perasaan), gaya belajar, kecerdasan majemuk, teknik memori, teknik membaca, teknik mencatat dan teknik belajar lainnya.

2. Upaya agar pembelajaran yang terjadi berlangsung dalam suasana yang kondusif yaitu suasana yang memperhatikan kondisi dan keadaan peserta didik serta menyenangkan. Ada tiga unsur yang menjadi landasannya, yakni:

a. Perasaan gembira. Dalam upaya menciptakan kondisi ini maka konsep edutainment mencoba memadukan pendidikan dan hiburan. Anak tidak bisa belajar efektif dalam keadaan stres. Belajar perlu dinikmati dan timbul dari perasaan suka serta nyaman tanpa paksaan. Untuk menciptakan lingkungan tanpa stres bagi peserta didik, penting bagi orangtua agar rileks dan tidak menetapkan target atau menuntut peserta didik melebihi kemampuannya.

b. Mengembangkan emosi positif peserta didik. Ketika suatu pelajaran melibatkan emosi positif yang kuat, umumnya pelajaran tersebut akan terekam dengan kuat pula dalam ingatan. Oleh karena itu, dibutuhkan kreatifitas guru dan orang tua untuk menciptakan permainan-permainan yang dapat menjadi wadah dan sarana peserta didik untuk belajar, misalnya melalui drama, warna, humor, dan lainlain.

c. Mengoptimalisasi potensi nalar peserta didik secara jitu akan mampu membuat loncatan prestasi belajar secara berlipat ganda. Bagian neokorteks dari otak terbagi dalam beberapa fungsi khusus seperti fungsi berbicara, mendengar, melihat dan meraba. Jika ingin memiliki memori yang kuat maka informasi harus disimpan dengan menggunakan semua indera-melihat, mendengar, berbicara, menyentuh, dan membaui. 


\section{Media Pembelajaran Edutainment}

Media pembelajaran yang digunakan dalam metode edutainment adalah alat-alat audio-visual. Yang tergolong dalam kategori audio-visual yaitu: media proyeksi (overhead projector, slide, film dan LCD), media non-proyeksi (papan tulis, poster,papa tempel,kartun, papan planel, komik, bagan, diagram gambar, grafik dan lain-lain, benda tiga dimensi antara lain benda tiruan, diorama, boneka, topeng, peta, globe, pameran dan museum (Sanaki, 2009: 38).

Menurut Okan (2003: 259), perlu ditelaah kembali menggunakan perangkat lunak dapat memotivasi siswa untuk mengeksplorasi pembelajaran lebih mendalam. Karena siswa sangat termotivasi melalui pengalaman belajar yang beragam dan menarik. Terlebih lagi, indra mereka akan terpesona dan terangsang pada semua aspek. Oleh karena itu, siswa selalu memperhatikan informasi yang disajikan dalam dinamis dan cara-cara yang mudah diingat. Namun, beberapa poin harus dipertimbangkan. Seperti menjelaskan bagaimana motivasi belajar terjadi, kemudian bagaimana teknologi tersebut dapat mendukung dan terlibatan dalam pembelajaran, kemudian apakan media pembelajaran tersebut tepat digunakan.

Pada umumnya, bahan pelajaran yang digunakan adalah buku paket yang disediakan sekolah, yang mana dalam hal ini merupakan bagian inti dari pembelajaran edutainment. Kemudian pendidik menggunakan media pendukung yang telah disinggung pada paragraf sebelumnya guna menciptakan pembelajaran yang menyenangkan. Saat ini seiring berkembangnya era

digital kemudian didukung internet yang semakin mudah untuk di akses, salah satu media pembelajaran berbasis komputer semakin menyenangkan bagi peserta didik. Berbagai macam bahan belajar dapat dicari dan dipelajari dengan sangat mudah, tentunya dengan mengevaluasi terlebih dahulu, apakah pembelajaran menggunakan komputer tersebut, benarbenar memotivasi belajar siswa.

\section{Manfaat Pembelajaran Edutainment}

Abdul Gani Jamora Nasution mengungkapkan, pada hakikatnya jika edutainment dikatakan sebagai model, strategi ataupun metode pembelajaran, namun tujuan akhir dari pembelajaran edutainment merupakan konsepsi pembelajaran yang dalam tatanan praktisnya peserta didik merasa senang, dan rasaa ingin tahu tentang mata pelajaran yang disampaikan oleh pendidik dapat tersampaikan (2017: 79).

Pembelajaran dikatakan menyenangkan apabila di dalamnya terdapat suasana yang rileks, bebas dari tekanan, aman, menarik, bangkitnya minat belajar, adanya keterlibatan penuh, perhatian peserta didik tercurah,lingkunganbelajar yang menarik, bersemangat, perasaan 


\section{Ulil Albab}

gembira, konsentrasi tinggi. Sebaliknya, pembelajaran menjadi tidak menyenangkan apabila suasana tertekan, perasaan terancam, perasaan menakutkan, merasa tidak berdaya, tidak bersemangat, malas/tidak berminat, jenuh/bosan, suasana pembelajaran monoton, pembelajaran tidak menarik siswa (Indrawati \& Wawan Setiawan, 2009: 24).

Manfaat pembelajaran edutainment ini berimplikasi kepada tujuan pembelajaran. Tujuan pembelajaran di Indonesia adalah mencerdaskan kehidupan bangsa, yang mana telah jelas dipaparkan dalam UU Sisdiknas tahun 2003. Kemudian langkah yang dilakukan untuk mencapai tujuan tersebuat adalah menciptakan suasana belajar yang menyenangkan. Kemudian langkah yang dilakukan untuk mencapai tujuan tersebuat adalah menciptakan suasana belajar yang menyenangkan. Karena belajar menyenangkan akan mempengaruhi kinerja otak dalam memproses, menyimpan dan mengambil informasi yang ada, sehingga tercipta proses belajar yang efektif dan proses belajar yang efektif ini dapat dilakukan dengan menerapkan konsep edutainment.

\section{Pendidikan Agama Islam}

Pendidikan Agama Islam merupakan gabungan dari tiga kata yaitu pendidikan, agama dan Islam. Pendidikan agama Islam pada dasarnya dapat dipahami dalam tiga aspek. Pertama, sebagai sumber nilai adalah jenis pendidikan yang pendirian dan penyelenggaraannya didorong oleh hasrat dan semangat cita-cita mengejawantahkan nilai-nilai Islam, baik yang tercermin dalam nama lembaganya maupun dalam kegiatan yang diselenggarakan. Kedua, sebagai bidang studi, sebagai ilmu, dan diperlakukan sebagai ilmu yang lain adalah jenis pendidikan yang memberikan perhatian sekaligus menjadikan ajaran Islam sebagai pengetahuan untuk program studi yang diselenggarakan. Ketiga, jenis pendidikan yang mencakup kedua pengertian di atas. Di sini kata Islam ditempatkan sebagai sumber nilai sekaligus sebagai bidang studi yang ditawarkan melalui program studi yang diselenggarakan. Islam yang telah diyakini menyeluruh, serta menjanjikan keselamatan hidup di dunia dan di akhirat kelak.

Sedangkan M. Arifin dalam Aat dkk (2008:11) mendefinisikan pendidikan Agama Islam adalah proses yang mengarahkan manusia kepada kehidupan yang lebih baik dan yang mengangkat derajat kemanusiaannya, sesuai dengan kemampuan dasar (fitrah) dan kemampuan ajarannya (pengaruh dari luar).

Pendidikan Agama Islam adalah usaha yang berupa pengajaran, bimbingan dan asuhan terhadap anak agar kelak selesai pendidikannya dapat memahami, menghayati, dan 
mengamalkan agama Islam, serta menjadikannya sebagai jalan kehidupan, baik pribadi maupun kehidupan masyarakat (Aat dkk, 2008:11-16). Dalam definisi lain, pendidikan agama Islam adalah suatu usaha bimbingan dan asuhan terhadap peserta didik agar nantinya setelah selesai dari pendidikan dapat memahami apa yang terkandung dalam Islam secara keseluruhan, menghayati makna dan maksud serta tujuannya yang pada akhirnya dapat mengamalkan dan menjadikan ajaran agama Islam yang dianutnya itu sebagai pandangan hidupnya, dapat mendatangkan keselamatan dunia dan akhirat (Samirin 2015 :105-106).

\section{Aplikasi Konsep Edutainment dalam PAI}

Menurut Porter, dalam edutainment sebagaimana quantum teaching, guru harus antusias (menampilkan semangat untuk hidup), berwibawa (mampu menggerakkan orang), positif (melihat peluang dalam setiap saat), supel (mudah menjalin hubungan dengan beragam siswa), humoris, berhati lapang untuk menerima kesalahan, luwes (menemukan lebih dari satu cara untuk mencapai hasil), menerima (mencari dibalik tindakan dan penampilan luar untuk menemukan nilai-nilai inti), fasih (berkomunikasi dengan jelas ringkas dan jujur), tulus (memiliki niat dan motivasi positif), spontan (dapat mengikuti irama, dan tetap menjaga hasil), menarik dan tertarik (mengaitkan setiap informasi dengan pengalaman hidup siswa dan akan diri siswa), menganggap siswa "mampu" (percaya akan kesuksesan siswa), menetapkan dan memelihara harapan tinggi (membuat pedoman kualitas hubungan dan kualitas kerja yang memacu setiap siswa untuk berusaha sebaik mungkin). (Bobbi De Poter, 1999:7-9).

Terdapat beberapa langkah untuk mengaplikasikan konsep edutainment dalam proses pembelajaran. Pertama, menumbuhkan sikap positif terhadap belajar. Pada proses pembelajaran berlangsung tidak berjalan secara murni, karena setiap siswa sering kali mengalami rasa takut, cemas, gagal, dan bahkan membosankan di dalam menerima materi pelajaran di kelas. Untuk itu, perlu adanya sikap dan berpikir positif terhadap siswa agar bisa menerima materi pelajaran seoptimal mungkin. Kedua, membangun minat belajar. Proses belajar edutainment harus dilandaskan pada bagaimana guru menjelaskan secara mudah dan dapat di pahami, baik menggunakan metode pembelajaran, menguasaimateri pelajaran dan menguasai tindakan kelas sehingga bisa bermanfaat terhadap pencapaian tujuan pendidikan agama Islam. Ketiga, melibatkan emosi siwa dalam pembelajaran. Artinya siswa mampu diarahkan untuk semangat mencari ilmu pengetahuan diberbagai macam bidang dengan cara penelitian tindakan kelas sehingga menemukan makna yang signifikan dan permanen.

Lebih lanjut Hamruni di dalam Mukaffan mengatakan desain pembelajaran yang perspektif edutainment berdampak pada: 1) membuat peserta didik merasa senang dan membuat belajar 


\section{Ulil Albab}

terasa lebih mudah; 2) mendesain pembelajaran dengan selipan humor atau mendesain humor dan permainan edukatif untuk memperkuat pemahaman materi; 3) penuh kasih sayang dalam beinteraksi dengan peserta didik; 4) menyampaikan materi pembelajaran yang dibutuhkan dan bermanfaat; 5) menyampaikanmateri yang sesuai usia dan kemampuan peserta didik dan; 6) memberikan pujian dan hadiah sebagai motivasi supaya peserta didik dapat berprestasi. Meski demikian pada kasusu tertentu pendidik dapat memberikan sanksi atau hukuman edukatif jika diperlukan (Mukaffan: 2013; 317)

Mengajarkan nilai-nilai Islam melalui proses pembelajaran, dikemas dalam mata pelajaran Pendidikan Agama Islam (PAI), di sekolah umum maupun madrasah atau lembaga pendidikan lainnya. Sosok pendidik menjadi aktor penting di kelas sebagai fasilitator dalam mengontrol peserta didiknya. Langkah-langkah dan tahapan yang dijelaskan dalam paragraf sebelumnya dapat menjadi acuan bagi guru Pendidikan Agama Islam mengaplikasikan pembelajaran di kelas.

Dalam mata pelajaran Pendidikan Agama Islam terdapat beberapa cabang. Yaitu, cabang ilmu ibadah (Fikih), tarikh (Sejarah Islam), al-Qur'an, akhlak dan ketauhidan. Aplikasi konsep edutainment dalam berbagai cabang ilmu agama Islam tersebut bervariasi.

Misalnya metode penerapan pembelajaran edutainment mata pelajaran PAI dapat berupa langkah-langkah sebagai berikut: Tujuan: melatih audio-visual siswa, dapat memiliki pemahaman dan mampu mepresentasikan apa yang telah dilihat. Alat yang diperlukan: LCD, laptop, dan film kartun yang durasi pendek sesuai dengan materi pembelajaran yang akan dilaksanakan, contohnya bab taharah. Cara bermainnya: guru membentuk tiga kelompok dan menyediakan kertas kosong untuk menulis nama kelompok dan tugasnya. Guru menuliskan tugas pada lipatan pesawat kertas, kemudian melemparkannya di kelas. Siapa yang dapat maka kelompoknya membaca tugas tersebut. Setiap kelompok mempresentasikan hasil yang telah didapat melalui film kartun. Setiap kelompok memberikan pertanyaan kepada kelompok rival disesuaikan dengan tugas dari guru. Jika tidak dapat menjawab pertanyaan dengan benar maka satu kelompok harus dihukum (Maftuh, 2017:129).

\section{KESIMPULAN}

Edutainment adalah suatu proses pembelajaran yang memadukan antara pendidikan dan hiburan, sehingga menjadi suatu desain pembelajaran yang menyenangkan dan menarik minat peserta didik untuk belajar. Secara mendasar edutainment membantu pesertra didik karena adanya upaya mengembalikan kondisi peserta didik sesuai dengan hakekat diri pesereta didik sebagi manusia. dengan keyakinan bahwa setiap peserta didik memiliki potensi diri yang dapat ditumbuhkembangkan melalui proses pembelajaran yang dilalui, dijalaninya. 
Teori Mutakhir Pembelajaran

Teori tentang edutainment ini tentunya tidak hanya dijadikan sebagai wacana belaka. Meskipun konsep ini tergolong baru, namun penerapannya telah dilakukan di lembaga pendidikan. Terdapat beberapa penelitian lapangan yang telah dilakukan, kemudian penulis membuat ikhtisar atas hasil dari penelitian tersebut lalu menuliskannya dalam bentuk artikel ini. Konsep edutainment dalam Pendidikan Islam, merupakan sebuah konsep pembelajaran yang memiliki spirit filosofis terhadap fakta yang bertebaran tentang pembelajaran. Untuk mencegah kebosanan guru dapat menerapkan belajar dan bermain menyenangkan sebagai pondasi awal dalam meningkatkan kualitas tumbuh kembang peserta didik. Anak dapat mengekspresikan diri dalam menjalani seluruh aktivitas, tanpa adanya paksaan, pengendalian dari para pendidik yang berada di sekitarnya, namun tetap mewujudkan prinsip belajar dan bermain menyenangkan hingga potensi yang ada berkembang optimal dalam diri peserta didik tersebut. 


\section{Ulil Albab}

\section{DAFTAR PUSTAKA}

Daulay, Nurussakinah. Struktur Otak dan Keberfungsiannya pada Anak dengan Gangguan Spektrum Autis: Kajian Neuropsikologi. Buletin Psikologi, 2017, Vol. 25, No. 1.

Hamid, M. Soleh. Tanpa tahun. Metode Edutainment. Yogyakarta: Diva Press.

Hamruni. 2009. Edutainment dalamPendidikan Islam \&Teori-Teori Pembelajaran Quantum, (Yogyakarta: Fakultas Tarbiyah UIN Sunan Kalijaga).

Indrawati, dan Setiawan, Wawan. 2009. Modul Pembelajaran Aktif, Kreatif, Efektif, dan Menyenangkan. Diterbitkan oleh PPPPTKIPA.

Maftuh, Hasan. 2017. Implementasi Konsep Edutainment pada Pembelajaran Pendidikan Agama Islam di SMP Negeri 1 Boyolali. Jurnal Inspirasi.Vol 1, No. 1 Juli 2017.

Mukaffan. 2013. Tren Edutainment dalam Metode Pembelajaran Pendidikan Agama Islam. Jurnal Tadris. Vol.8, Nomor 2. Desember 2013.

Okan, Zuhal. 2003. "Edutainment: is learning at risk?" British Journal of Educational Technology, Vol 34 No 32003.

Sanaky, Hujair A.H. 2009. Tujuh Kompetensi yang Menyenangkandan Profesional,Yogyakarta: Power Book.

Sanaky, Hujair A.H. 2013. Media Pembelajaran Interaktif- Inovatif. Kaukaba Dipantara. Yogyakarta.

Suyadi. $\quad$ 2010. Psikologi Belajar PAUD (Pendidikan Anak Usia Dini). Yogyakarta: P.T. Pustaka Insan Madani.

Trinova, Zulvia. 2012. Hakikat Belajar Dan Bermain Menyenangkan Bagi Peserta Didik. Jurnal Al-Ta'lim, Jilid 1, Nomor 3, hlm. 209-215.

Syafaat,GAaffi nddn Bahsadha, Sohari. 2008. Peranan Pendidikan Agama Islam. Jakarta: Pt. Raja

Jamora Nasution, Abdul Gani. Pembelajaran Edutainment: Tinjauan Filosofis Pendidikan Islam. ، العربية إحياء السنة الثالثة العدد 2 يوليو 2 ديسربر

De Porter, Bobbi., dkk. 1999. Quantum Teaching: Mempraktikkan Quantum Learning di Ruang-Ruang Kelas, terj. Ary Nilandari. Bandung: Kaifa. 